\title{
Implementation of International Legal Standards in the Revision of the Judgements that are in Force by Supreme Court of Finland
}

\author{
Vladimir Jilkine \\ Mg. iur. Doctorant of Law, Counsel, Finland \\ info@lawcenter.fi
}

\begin{abstract}
The article deals with the basis and procedure for review of court decisions that have entered into force, after the rulings of the European Court of Human Rights on violations of the Convention for the Protection of Human Rights and Fundamental Freedoms in review of the cases by the Supreme Court of Finland, in connection with the decision by which the applicant appealed to The European Court of Human Rights. The author's analysis and comparison of judicial practice and the European legal system shows that when making decisions, the Supreme Court applies current national constitutional and legislative provisions.
\end{abstract}

Keywords: European Court of Human Rights, human rights, the conviction, the international law.

\section{Introduction}

In 1990, Finland had already ratified the Convention on the Protection of Human Rights and Fundamental Freedoms and thereby recognised it as a part of its legal system, and the jurisdiction of the European Court of Human Rights (ECHR), by virtue of Article 46 of the Convention, ipso facto and without special agreement - obligatory for the interpretation and application of the Convention and its Protocols in cases of alleged violation. Accordingly, since the decision of the ECHR implies acceptance by the respondent State of specific measures for its execution, the person against whom the violation of the Convention has occurred should be able to apply to the competent court for review of the judicial act, give rise to the complaint with the ECHR, and to be sure that his application will be considered. 
Vladimir Jilkine. The implementation of international legal standards in the revision of the judgements that are in force by Supreme Court of Finland

According to Recommendation No R (2000) 2 in exceptional cases, the most effective way to new investigation of the case is for the applicant to return to an earlier stage. In particular, when the applicant, after the decision of the Court of Human Rights, is still suffering post sentence of a national court as a consequence of serious adverse effects that cannot be fixed without a new investigation at a national level. An example would include such consequences specified in the recommendation of a long prison sentence, which the convicted person is still serving [1]. The recommendation encouraged all Contracting Parties to ensure that their national legal systems have necessary abilities to achieve, as far as possible, restitutio in integrum, and in particular to provide appropriate opportunities for case review, including reopening of the case.

Currently, national law of many European countries provides for the review of judicial decisions, which have entered into force, in order to remedy the consequences of violations found by the European Court. In Austria, Bulgaria, Germany, Greece, Lithuania, Luxembourg, Malta, Norway, Poland, Slovenia, the United Kingdom, France, Croatia and Switzerland, internal law establishes such a right. A number of states clearly allows for the possibility of judicial review of decisions by a broad interpretation of general constitutional or legal provisions, such as Belgium, Denmark, Spain, Slovakia, Finland and Sweden. Jurisprudence of other member countries of the Convention contains sufficiently flexible provisions, which, if necessary, can be interpreted so that a review of final judgments in the given situation was possible.

\section{Aim}

The purpose of the study is to determine the meaning of the decisions by the ECHR for the national proceedings in Latvia and Finland.

\section{Material and Methods}

Dialectical method was used in the analysis of the implementation of the European Convention while maintaining sovereignty of the Member States of the Council of Europe. Formal-logical method was used to study the provisions of the Constitutions of the Republic of Latvia and Finland, the European Convention, the European Court, and others.

Historical method, however, has allowed to consider the most vital stages of development of the control mechanism of the European Convention. Comparativelegal method was used as a foundation for the study of the placement of the European Convention in the legal system of the Member States of the Council of Europe. 
Vladimir Jilkine. The implementation of international legal standards in the revision of the judgements that are in force by Supreme Court of Finland

\section{Discussion}

\section{Review by the Supreme Court of claims for abolishing an earlier decision of the court after recognition of ECHR article/articles of the Convention breach}

The author believes that in spite of the commitments taken up by Finland to make every effort for the realisation of the right to a fair trial, in practice a formalistic approach has to be noted.

In particular, the Supreme Court often refers to the earlier decision KKO:2008:24 [2], which established that a conviction does not mean that the earlier made decision of the national court should be lifted. Using the example of the decision KKO:2008:24, the Court noted that the legislation of 1960, concerning the abolition of the sentence that came into force, does not fit into the situation relating to the decisions of the European Court of Human Rights. In the same decision, the court stated that the Finnish legislation does not include specific provisions for the abolition of national convictions and the grounds for re-examination of cases on the basis of a violation of the ECHR violations except those of Chapter $31 \$ 2$ sub-paragraph 3 of the Procedural Code for the submission of the claim deadline.

In practice, the Supreme Court of Finland, for example, in the decision (KKO:2009:84) [3] found that the European Convention on Human Rights as such does not oblige participating States to engage in the cancellation or annulment of the sentences of national courts in the statement of the European Court of violations of Article 6 of the Convention for fair trial. Prerequisites for further appeal, i.e. claim for annulment of the verdict and complaint application for judicial error (in particular this new case was solely about the complaint regarding a procedural error), it is necessary to assess each situation on the basis of the national law of the participant State of the convention.

During the period from 1995 to October 1, 2015 in 133 cases the ECHR found violations made by Finland of one or more articles of the Convention for the Protection of Human Rights and Fundamental Freedoms. On the basis of the European Court decisions in the recognition of a violation of articles of the Convention, the applicants filed multiple actions for cancellation of prior decisions to the Supreme Court.

After reviewing all the decisions of the Supreme Court of Finland for the period of 2010-2014, the author presents the following data. During this period, the SC of Finland issued just $\mathbf{1 5 6}$ decisions to change previously made decisions of national courts.

The author emphasises that, on the one hand, the Convention and its Protocols are important for Finland as a Participant State, as well as the case law of the ECHR, which the Supreme Court constantly refers to. On the other hand, the SC applies current national constitutional and legislative provisions, in particular Procedure Code of 1960 with 2005 amendment to abolish the court order, which was previously imposed and has entered into force. 
Vladimir Jilkine. The implementation of international legal standards in the revision of the judgements that are in force by Supreme Court of Finland

As a result of consideration of claims based on the decisions of the ECHR recognising one or more violations of articles of the Convention, none of the earlier decisions by national courts of Finland were immediately and completely abolished in all the articles of the allegations of coercive measures, the full amount of the damage or the size of the court costs.

At the same time the SC of Finland decides to abolish all or part of the charges that came into force of the decisions handed down by national courts, complaints that have not been filed and reviewed by the ECHR in violation of articles of the Convention. For example, the authors cite the demonstrative decision made by the Supreme Court of Finland in KKO:2011:109, the Supreme Court twice in 2011 returned the criminal case of Jippii Group Oyj for the review by the Court of Appeal of Helsinki. The Supreme Court referred to $\$ 21$ of the Finnish Constitution and Article 6 of the European Convention, which guarantees everyone the right to a fair trial and judicial precedents of the European Court.

The conclusion in the investigation of suspicions between 2000-2011 in economic crimes arrived on 21.12.2012 when, after 24 hearings, the Court of Appeal of Helsinki found 14 accused to be not guilty, abolished all 26 counts in the indictment and ordered the state to pay the defendants approximately 4 million euros legal costs. In reaching a decision, the court took into account the earlier rulings of the ECHR in violation of Article 6 of the Convention [Foucher v. France. 18.03.1997; Kahraman v. Turkey, 31.10.2006; V.v. Finland, 24.04.2007].

The author of the criminal case, senior Inspector Keijo Suuripää, most fully represents a real picture of the recognition of judgments of the ECHR and the protection of human rights in Finland, the time frame of the proceedings compared to the size of the gained benefit and the final judgment.

Keijo Suurpää was elected the Chairman of the police rally driving club called Handcuff Team Police Finland ry. In May 1998, the applicant took part in a rally in Belgium with a car he had rented. As he was bringing the car back to Finland, the Customs Authorities took note of the fact that the registration of the car had been changed. They started a criminal inquiry into the matter. On July 7, 1998, the Office of the Prosecutor General decided that a police investigation should be carried out into whether the applicant had been aware of the change in the registration. The money 18,000 FIM (approximately 3,000 EUR) in question had been intended expressly as financial support for the applicant (the navigator) and another policeman (the driver) in the rally.

On 22.06.2000 Court of Appeal reversed the charges of taking bribes and unintended malfeasance presented by district public prosecutor. The public prosecutor appealed to the Supreme Court, in its decision from 13.06.2002 Suuripää was sentenced to a fine at the rate of 40-day income for bribery and payment received from the state crime of economic benefits in the amount of 3,027 euros [4]. 
Vladimir Jilkine. The implementation of international legal standards in the revision of the judgements that are in force by Supreme Court of Finland

The applicant appealed to the ECHR. There has accordingly been a breach of Article $6 \$ 1$ of the Convention in respect of the lack of a verbal testimony and a violation of Article $6 \mathbb{\$} 1$ of the Convention in respect of the length of the proceedings.

After the judgment by the ECHR Case of Suuripää v. Finland on violation of Article 6 of the Convention, the State Chancellor of Justice filed a lawsuit against the abolition of the Supreme Court decision from 13.06.2002 on the basis of procedural error, which could materially affect the final verdict. The Chancellor referred to a ruling by the ECHR from 12.01.2010 for the recognition of Finland's violation of Article $6 \$ 1$ when considering criminal cases, the Supreme Court ruled that a verbal testimony of Keijo Suuripää is not necessary.

In a case from 24.05.2012 [5] the SC referred to the Recommendation of the Council of Ministers of the Council of Europe - Recommendation No R (2000) 2 [6] on the re-examination of cases in national courts when the injured party did not have the time or opportunity to prepare his defence in criminal proceedings.

The decision from 24.05.2012 of the Supreme Court en banc of 12 judges overturned the earlier decision of the Supreme Court from 13.6.2002 and referred the case to the Judicial Chamber of the Supreme Court of five judges [7]. Trial Division of the Supreme Court consisting of 5 judges considered the case again on 08.10.2012. In the new trial the State prosecutor also claimed the loss to the state resulting from the economic benefits by the committed crime in the amount of 3,027 euros.

The Supreme Court did not change the final result of the Court of Appeal as well as the demand for the return of Suuripää expenses previously paid to the state in the sum of 15,964 euros were left without review.

Also, according to the author an important example of the lawsuit in the SC, and a decision is the case of the former tax service expert Anna-Liisa Mariapori. Acting as a witness for the defence in court of Lappeenranta on 3 December, 1997, which considered the case of tax offenses, Mariapori stated that senior tax inspector Nissinen Grönroos has deliberately distorted the expert assessments in the tax decision not supported by the facts and therefore suspected of official crimes. The difference between the applicant's estimation of the defendant's taxable income and the estimation given by the tax inspectors was about 2.5 million Finnish Marks (about 494,000 euros).

According to article 24 of the Criminal Code $\$ 10$ Finnish court sentenced Mariapori to 4-month suspended prison sentence for defamation of a person, and also ordered the state to transfer Mariapori's books, CD-ROMs, as well as the possible copies, if books and subjects of manufacturing did not have any changes, Nissinen also had to pay for the anguish a sum of 5,000 euros. The court ordered Mariapori to pay legal costs to employees and the State Tax Service in the amount of 36,895.03 EUR, excluding accrued interest.

The European Court of Human Rights in Mariapori v. Finland (37751/07) on 6 July 2010 ruled that Finland in the verdict of Mariapori violated the $10^{\text {th }}$ article of the Charter of Human Rights and the $1^{\text {st }}$ paragraph of Article 6 of the Charter 
Vladimir Jilkine. The implementation of international legal standards in the revision of the judgements that are in force by Supreme Court of Finland

at the excessive length of the process. The ECHR decided to pay compensation to Mariapori in a sum of 49,390 euros.

When considering a claim for an abolishment of the decision by the Supreme Court [8] that has entered into force on the verdict, referring to the application in practice of Article 46 of the Convention believed that the ruling by the ECHR on Mariapori v. Finland not only obliges the Member States of the Treaty by the final judgment of the Treaty obligations and to pay compensation to victims, but also an obligation under the supervision of the European Committee of Ministers by the final supervision of the implementation of the decisions and the impact of the elimination of violations. At the same time, the Supreme Court referred to the earlier decision KKO:2008:24, which established that a conviction does not mean that the earlier decision of the national court should be lifted anyway.

As part of the criminal prosecution, the Supreme Court did not abolish criminal penalties, but only a consequence of the sentence, that is, repealed the probation period, which ended back on 31.07.2005.

The Supreme Court ruled that because the prosecution of Mariapori has not been lifted, there is no reason to oblige the government to compensate the cost of the Supreme Court. The Supreme Court found no reason to cancel the sentence in particular compensation damages to Nissinen in the amount of 5,000 euros. The SC also ruled that designated compensation set by the European Court was sufficient for the state to cover legal expenses that Mariapori should compensate plaintiffs, due to there being no grounds for overturning a verdict in this part [9].

In other parts of the claim the SC has ruled that there is no viable cause for the abolition of the sentence pursuant to article $31 \$ 8$ Procedure Code of Finland. The SC noted that the Court of Appeal reversed the decision only in part of the criminal sentence, which, as stated above, was conditional and its validity ended more than 6 years ago.

This case clearly characterises the State using the Supreme Court as a tool to evade execution of judgments of the European Court. This is just one of many such cases in which the $\mathrm{SC}$ of Finland adheres to this policy in the process of interpretation of the European Court.

According to the author the most telling example in the application of constitutional or legislative rules, terms of cases, the size of legal costs and the impact of the final decision of the Supreme Court of Finland for changes in legislation and the importance of this decision for the applicant to be considered at all stages of the national courts of Finland and the ECHR from 1994 to 2010, is the criminal process of brothers Kari Uoti and Jussi Uoti.

The late 80s saw an investigation of economic crime, where LSP-bank suffered losses amounting to about 134 million euros from unpaid real estate investments.

The suspect in this case was a businessman and lawyer Kari Uoti, in December 1997 affidavit of liability for perjury did not report part of their property during the preliminary investigation on suspicion of serious tax crimes related to the sale of 
Vladimir Jilkine. The implementation of international legal standards in the revision of the judgements that are in force by Supreme Court of Finland

shares in 1993 of Interbank. Kari Uoti believed that during the criminal investigation into suspicions from the $90 \mathrm{~s}$, and also in the investigation of serious crime of the debtor he had no obligation to report his personal assets to their bankruptcy property manager and that the suspect had the right to remain silent.

Jussi Uoti was declared bankrupt in 1997 and ordered, in December 1998 under oath, to make an inventory of the bankruptcy estate. At the same time he was charged with the crime of tax debtor for the amount of debt of 87 million euros and tax fraud under aggravating circumstances. Suspect affidavit of liability for perjury concealing from the bankruptcy administrator of the property, transferred to offshore companies.

In 1999, the district court of Helsinki sentenced Jussi Uoti to 5 years and 8 months, and Kari Uoti to 6 years in prison, which came into force in 2001, after consideration of the case by the Court of Appeal in Helsinki.

On 21.03.2006, Salo district Court rendered the decision which sentenced Kari Uoti for a grievous offense as the debtor to 6 months and 20 days in jail and former director of the Bank Interbank Juha Sorvisto to one year and 6 months in prison, as well as ordering payment of damages of more than 12 million euros to property bankruptcy management company Arsenal.

On 07.01.2007, the ECHR found a violation of Article 6 of the Convention and pointed to the long-term of procedural time with the case of Kari Uoti starting in August 1994 and lasting for 11 years and 7 months, and has ordered the respondent State to pay 5,220.24 Euros for legal costs compensation.

On October 23, 2007, the ECHR ruled that the case of Jussi Uoti holds that there has been no violation of Article $6 \$ 1$ and $\$ 3$ (d) of the Convention taken together; has been no violation of Article $6 \$ 2$ of the Convention.

The court of second instance commuted his sentence in Helsinki with Kari Uoti to serve 4 months in prison. Finland's Supreme Court in its judgment from 17.04.2009 indicated that Uoti had no right to evade testifying under oath, found him guilty of the crime and sentenced to 5 months and 10 days imprisonment.

Four days later, on April 21, 2009, the Court delivered its judgment in the case of Marttinen v. Finland (no. 19235/03, 21 April, 2009) in which it found that there had been a violation of the applicant's right to silence and his right not to incriminate himself guaranteed by Article $6 \$ 1$ of the Convention.

"... The application of the right not to incriminate oneself [as provided for in the Convention] to the debt recovery procedure might hinder effective enforcement without cause." [10]

The Supreme Court of 20.10.2009, for the first time, with reference to the recognition of a violation by Finland in Marttinen v. Finland abolished criminal conviction of Kari Uoti (this ruling should not be confused with the verdict of the Court of Appeal of Helsinki from 30.03.2001 which defined a punishment of 6 years), as well as freeing him from paying the bankruptcy mass of 2,189,982.62 USD and 3,006,754.91 DEM. 
Vladimir Jilkine. The implementation of international legal standards in the revision of the judgements that are in force by Supreme Court of Finland

At the same time, this solution cannot be considered to have completely abolished the previous sentence. While cancelling a prior ruling by the Supreme Court in regards to the prison sentence of 5 months and 10 days, the court has not overturned decision that Kari Uoti previously imputed in terms of weight of the total Bankruptcy payments of 1,187,981.63 EUR and 1,557,181.76 USD.

In December 2006, Salo County Court sentenced Jussi Uoti to 1 year and 2 months in prison. Turku Court of Appeal has determined criminal penalties of imprisonment for 11 months for tax fraud in a large scale (shares of the company housing and property valued at more than 11.4 million euros) in accordance with paragraph 1 of persecution [11].

On 02.12.2010 in its decision the Supreme Court quashed the charge brought against Jussi Uoti as a felony tax debtor [12]. 2 count-forgery of a document - the sentencing court found sufficient and final penalty appointed by absorption of less severe by stricter punishment. The court freed Jussi Uoti from covering legal costs of bankruptcy estate in the district and appellate court in the amount of 170,756.09 euros.

The rest of the appellate court decision was left unaltered by the SC.

Among those convicted by Turku Court of Appeal in 2006, together with Kari Uoti was the former director of Interbank Juha Sorvisto, sentenced to 1 year and 6 months imprisonment. The court also awarded damages to the Arsenal bank of 11 million euros.

In the case of Case of Sorvisto v. Finland [13] the ECHR found a violation of Article $6 \$ 1$ and Article 13 of the Convention on account of the excessive length of civil court proceedings and the lack of effective mean of juridical protection in this respect.

When considering a claim for abolition of Sorvisto's sentence [14], the SC pointed out that the recognition of a violation by the ECHR is not a valid reason to cancel the decision of the national court in accordance with section $4 \$ 8$ of Chapter 31 of the Procedural Code for abolition of the previous sentence ruled by the court and as a result has dismissed the claim.

Also, in the case of the Uoti brothers the LSP Bank lawyer Ari Lehtonen was convicted to 4 years and 6 months imprisonment with an estimate damages of 23.5 million euros. On 17.2.2003, the Supreme Court rejected his case review, and Lehtonen filed a complaint with the ECHR. On 13 June, 2006, the ECHR held that there had been a violation of Article $6 \$ 1$ and a violation of Article 13 of the Convention.

Despite the violations of the Convention, the Supreme Court examined the three claims made by Ari Lehtonen, two of which were dismissed and one is currently under consideration.

In the case of Kari Uoti, former professor of commercial law (stripped of his rank after the verdict) and Doctor of Law, Ari Huhtamäki, was convicted under article of non-confidence to the debtor for concealing assets of Kari Uoti during the bankruptcy. 
Vladimir Jilkine. The implementation of international legal standards in the revision of the judgements that are in force by Supreme Court of Finland

When considering a claim from 22.06.2010 for abolition of criminal conviction, the Supreme Court ruled that, although the case mentions the overturned verdict for Kari Uoti and the charges were dropped, this does not mean that the accusation directed at Huhtamäki can be dismissed.

\section{The Value of the Judgment by the ECHR on \\ Marttinen v. Finland for further Changes to the Legislation of Finland}

A particularly important role in the jurisprudence of Finland was played by a decision from 2009 by the ECHR Marttinen v. Finland and subsequent ruling by the Supreme Court to abolish an earlier criminal conviction of Kari Uoti, which marked the beginning of revisions in Finnish legislation and subsequent amendments, which provide guarantees for suspects in criminal cases in accordance with the universally recognised norms of international law.

The Ministry of Justice has acknowledged that the current system in which users of law directly apply $\$ 1$ and $\$ 21$ of the Constitution of Finland, as well as the International Covenant on Civil and Political Rights, and orders relating to legitimate judicial practice agreements on civil rights, did not work so that control procedure of Bankruptcy was sufficiently clear and predictable.

Ministry of Justice of Finland, in January 2010 appointed a working group to amend the Law on Bankruptcy and renovate the $17^{\text {th }}$ chapter of the Procedural Code.

Finnish Bankruptcy Law, as amended, came into force on 01.01.2013; the effect of the new article "Protection against self-incrimination" $\$ 5[31.01 .2013 / 86]$ entered into force on 31.01.2013:

"If the debtor is a suspect in pre-trial investigation or accused of a crime, he is not obliged to give the bankruptcy administrator information on the facts on which the suspicion is based."

Nevertheless, the author also stresses that the case of Marttinen lasted for more than nine years and, under consideration of the application for abolition of the sentence, the SC ruled that the grounds for the quashing of the final decision of the court stated in accordance with chapter $31 \$ 8$ are not available. Basis for refusal of Marttinen criminal conviction abolition by the Supreme Court are in reference to the case of Kari Uoti KKO:2009:80 and national legislation. The SC pointed out in the decision that the court ruling on human rights with the delay shows that Marttinen should not have been sentenced to pay a court fine for failing to appear in court. Marttinen still has not paid his court fine imposed for failure to appear in court as well as not substituted the payment of a fine by serving a prison sentence. The Supreme Court determined that the amount of the fine imposed by the court expired five years after the decision of the court, so a decision on the payment of the fine is no longer enforceable. Subsequently Marttinen was not hurt, and no longer suffers from the negative consequences of the decision on the payment of the fine. 
Vladimir Jilkine. The implementation of international legal standards in the revision of the judgements that are in force by Supreme Court of Finland

Thus, the Supreme Court held that in this case there are no grounds on which the court decision that has entered into force might be revoked in accordance with Chapter $31 \$ 8$ of the Procedural Code.

\section{Review by the Supreme Court of Claims \\ from 12.12.2014 regarding a Breach \\ of the ne bis in idem Principle}

The author also cites an example of four ECHR decisions against Finland from 20 May, 2014. In two of them the ECHR found a violation of the principle of ne bis in idem and Article 4 of Protocol No 7 to the Convention and ordered the respondent State to pay compensation for moral damages and all legal costs [Glantz, Nykänen, Häkkä, Pirtimäki]. All four, as well as J. Kangasvieri and T. Rintala, with reference to the recognition of violations of the ECHR from 20.05.2014 have applied for abolition of the earlier decisions.

On 12.12.2014, the Supreme Court found in all 6 of the decisions that the conditions of revocation should be evaluated on the basis of national legislation, even if the basis of an application is a conviction of the ECHR.

When considering a claim for abolition of the sentence in the KKO:2014:95 Glantz from 12.12.2014, the Supreme Court pointed out that the decision of the ECHR does not imply that the finding of a violation of the Convention does not require the abolition of the sentence. In the jurisprudence of the Supreme Court there are many cases which request dismissal of such decisions made by national courts.

The SC noted that the decision of the KKO:2009:80 concerned circumstances (self-incrimination suspect in bankruptcy) which were not taken into account in the legislation adequately; however, those were later rectified.

The Supreme Court's decision in the case of Kaj-Erik Torsten Glantz consists of 34 pages and 26 references to the decisions of the ECHR and 12 references to the earlier decisions of the Supreme Court, which provides a ground for refusal for abolition of the verdict by the national court.

The Supreme Court referred to Chapter $31 \$ 8$ of the Procedural Code, according to which the sentence in a criminal case can be revoked in favour of the defendant if the decision was based on a clearly erroneous application of the law.

The SC has revoked an action of only one of eight counts in the rest of the claim and referred the case to the judicial board of the five judges.

\section{Results and Evaluation}

In recent decisions, the Supreme Court increasingly and repeatedly refers to the decisions and case law of the ECHR, in detail justifying the reason for refusal, referring to international practice and its own case law. In practice, after finding a violation of the ECHR by the respondent State of Articles of the Convention, none of the earlier 
Vladimir Jilkine. The implementation of international legal standards in the revision of the judgements that are in force by Supreme Court of Finland

decisions were abolished completely, and the timing of consideration of cases as well as the amount of legal costs point to a weak defence of human rights and the need for radical change of the existing situation in the judicial system.

During the study, 133 ECHR judgments against Finland in the period of 1995-2015 were analysed, which found violations of articles of the ConventionConsidering the grounds for rejection of claims absolving prior rulings by the national courts, the author allows for the following conclusions:

1. In accordance with the provisions of Article 46 of the Convention, interpreted by taking into account the recommendations of the Committee of Ministers of the Council of Europe No R (2000) 2 on January 19, 2000, the basis for judicial review of the act due to new circumstances is not only based of violation by Finland established in the European Court but also the Convention or the Protocols. In this regard, it should be appreciated that a judicial act is subject to review in the event that the applicant continues to suffer adverse effects of such an act and paid compensation to the applicant awarded by the Court pursuant to Article 41 of the Convention does not provide a remedy and freedoms.

2. The principle of the presumption of innocence, provisions of Article $6 \$ 2$ of the Convention, is one of the main aspects of fair trial in the criminal case law.

3. On the basis of Article 46 of the Convention, taking into account recommendations for revision in case of violation of the procedural rights of individuals found by the European Court, the Supreme Court in the revision of a judicial act must eliminate violation of the Convention or the Protocols thereto. The Supreme Court must take the same stance as the court in Strasbourg and adopt a final judicial act, instead of taking the decision to return the case to the appellate court.

\section{Conclusions and Evaluation}

Based on the study of the Supreme Court of Finland's decisions, it is possible to make the following conclusions. The Supreme Court, after the decision by the ECHR against Finland in the review of cases and applications for cancellation of the sentence, makes decisions by applying national legislation and is guided by the protection of national government agencies and are not guided by the principles of the rule of international law.

Since national judicial act is not a subject to revision in the international jurisdiction, the state made a commitment to adopt the final judgments of the ECHR, which require abolition of prior judicial decisions made in framework of national jurisdiction and must be entered in national legislation of a mechanism to restore the rights of applicants. 
Vladimir Jilkine. The implementation of international legal standards in the revision of the judgements that are in force by Supreme Court of Finland

The author concludes that despite numerous references to the case law of the ECHR, the Supreme Court of Finland decides by national legislation, in particular Procedure Code of 1960. Therefore, despite the fact that the first attempts were made for the implementation of the legal system of the Finnish judicial precedent as a source of law in the form of judgments and commitment of their decisions, the mechanism for the functioning of judicial precedent requires improvement and amendments to the legislation.

According to the authors cited, there is a distinct lack of compatibility of Article 6 of the Convention with the regulatory provisions of the Finnish legislation, in particular in the Procedural Code of Finland having no grounds for overturning a verdict, based on recognition by the ECHR, with violations of articles of the Convention, leading Supreme Court of Finland not making decisions on abolition of prior court decisions which have entered into force, thereby avoiding both the implementation of decisions made by the ECHR and severe need to improve and update the national legal system to guarantee opportunities restitutio in integrum for the injured party.

\section{References}

1. Recommendation No R (2000) 2 of the Committee of Ministers to member states on the re-examination or reopening of certain cases at domestic level following judgements of the European Court of Human Right. (Adopted by the Committee of Ministers on 19 January, 2000 at the $694^{\text {th }}$ meeting of the Ministers' Deputies) i.3.

2. Judgment of Supreme Court, case of Selistö on 14.03.2008.

3. Judgment of Supreme Court, case of Eino Laaksonen on 27.10.2009.

4. Judgment of Supreme Court KKO:2002:51, 13.06.2002.

5. Judgment of Supreme Court R2010/116, 24.05.2012.

6. Recommendation No R (2000) 2. Art. 12.

7. Judgment of Supreme Court H2010/116, 24.05.2012.

8. KKO:2011:100, Judgment of Finnish Supreme Court, 22.11.2011.

9. KKO:2011:100, Judgment of Finnish Supreme Court, 22.11.2011/ para 36.

10. Case of Marttinen v. Finland (no. 19235/03, 21 April, 2009. http://hudoc.echr.coe.int/ eng\#\{“fulltext": ["Case of Marttinen v. Finland"],"documentcollectionid2”:["GRANDCHAMB ER",CCHAMBER”],"itemid":["001-92233”]\}

11. Decision of the Appear court of Turku on 25.06.2008 No 1420.

12. Judgment of Supreme Court, No R2008/876, on 02.12.2010.

13. Case of Sorvisto v. Finland, No 19348/04, 13 January, 2009.

14. http://hudoc.echr.coe.int/eng\#\{“fulltext": ["Case of Sorvisto v. Finland”], "documentcollectioni d2":["GRANDCHAMBER”,"CHAMBER”],"itemid”:[“001-90581”]\}

15. Judgment of Finnish Supreme Court, 11.11.2011.; H2009/174. 